\title{
EFFECTS OF TRAINING LOAD CHANGES ON PHYSICAL PERFORMANCE AND EXERCISE-INDUCED MUSCLE DAMAGE
}

\author{
EFEITOS DAS MUDANÇAS DE CARGA DE TREINAMENTO SOBRE O DESEMPENHO FÍSICO E DANO \\ MUSCULARINDUZIDO POREXERCÍCIO
}

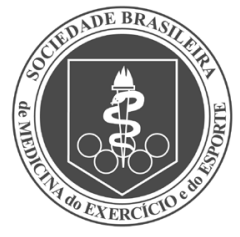

Original Article

Artigo OrIGINAL Artículo Original

\author{
EFECTOS DE LOS CAMBIOS DE CARGA DE ENTRENAMIENTO SOBRE EL DESEMPEÑO FÍSICO Y DAÑO \\ MUSCULARINDUCIDO POREJERCICIO
}

Selcen Korkmaz Eryllmaz ${ }^{1}$

(Physical Education Professional)

Zübeyde Aslankeser ${ }^{2}$

(Physical Education Professional)

Çiğdem Özdemir ${ }^{3}$

(Physiologist)

Kerem Özgünen ${ }^{3}$

(Physiologist)

Sadi Kurdak ${ }^{3}$

(Physiologist)

1. Çukurova University, School of Physical Education and Sports, Balcalı, Adana, Turkey.

2. Selçuk University, Faculty of Sport

Science, Konya, Turkey.

3. Çukurova University, Faculty of Medicine, Department of

Physiology, Division of Sports

Physiology, Balcalı, Adana, Turkey.

\section{Correspondence:}

Selcen Korkmaz Eryılmaz. Çukurova University, School of Physical Education and Sports, Balcalı, Sarıçam, Adana, Turkey.1380. selcen_korkmaz@yahoo.com

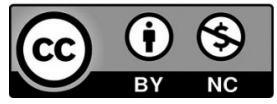

\begin{abstract}
Introduction: There is no previous study examining muscle damage responses from training load changes in individuals trained exclusively with repeated sprint exercise. Objectives: The purpose of this study was to examine the effect of training load changes on physical performance and exercise-induced muscle damage in male college athletes who were trained using a 30m repeated sprint protocol. Methods: Twelve participants completed the 6 -week training period (three sessions/week), which consisted of progressively increasing intensity training in the first 5 weeks. On the first day of the training period, all sprints were performed at 70-80\% of maximum effort. In the first session of the $5^{\text {th }}$ week (Maximal intensity training; MIT), all sprints (10x30m sprints) were performed at maximal speed. The sets (10 sprints at maximal speed in each set) were repeated until exhaustion (Exhaustive training; ET) in the first training session of the $6^{\text {th }}$ week, followed by two sessions of the normal training. Isometric strength, $30 \mathrm{~m}$ sprint performance, flexibility, serum creatine kinase (CK) and cortisol were measured periodically during the examination period. Results: Isometric strength, 30m sprint performance, and flexibility were significantly decreased following the ET, and did not recover during the following 9-day period, which consisted of two training sessions and 6 days of recovery. Cortisol was significantly elevated immediately after the ET but was not changed after training on first day and during MIT. CK was significantly elevated after training every week, but the increase at 24 hours after ET was significantly higher than after the first day and MIT. Conclusions: Dramatically increasing the volume of maximal intensity repeated sprint exercise results in greater relative muscle damage even in trained individuals, which will significantly limit their performance. Further training sessions, even at normal intensity and volume with insufficient time for muscle recovery, may prolong the duration of fatigue. Level of evidence ll; Diagnostic Studies - Investigating a diagnostic test.
\end{abstract}

Keywords: Creatine kinase; Cortisol; Flexibility; Muscle strength; Sprint interval training; Muscle Fatigue.

\section{RESUMO}

Introdução: Não existe nenhum estudo anterior que tenha analisado as respostas às lesões musculares decorrentes das alterações da carga de treinamento em indivíduos treinados exclusivamente com exercícios repetitivos de corrida. Objetivos: A proposta deste estudo foi examinar o efeito das alterações da carga de treinamento sobre o desempenho físico e as lesões musculares induzidas pelo exercício em atletas universitários do sexo masculino que foram treinados usando um protocolo de sprint (treinamento de alta intensidade) de 30 metros repetido. Métodos: Doze participantes concluíram o período de treinamento de 6 semanas (três sessões/semana), que consistiu em aumentar progressivamente o treinamento de intensidade nas primeiras 5 semanas. No primeiro dia do período de treinamento, todos os sprints foram realizados com $70 \%$ a $80 \%$ do esforço máximo. Na primeira sessão da 5 a semana (treinamento de intensidade máxima, TIM), todos os sprints $(10 \times 30 \mathrm{~m})$ foram realizados na velocidade máxima. As séries (10 sprints na velocidade máxima em cada série) foram repetidas até a exaustão (treinamento exaustivo, TE) na primeira sessão de treinamento da $6^{a}$ semana, seguidas de duas sessões de treinamento normal. A força isométrica, o desempenho no sprint de 30 metros, a flexibilidade, a creatina quinase sérica (CK) e o cortisol foram medidos periodicamente durante o período de treinamento. Resultados: A força isométrica, o desempenho no sprint de 30 metros e a flexibilidade diminuíram significativamente depois do TE e não foram recuperados durante o período de 9 dias seguintes, que consistiu em duas sessões de treinamento e 6 dias de recuperação. O cortisol teve elevação significativa imediatamente após o TE, mas não teve alteração depois do treinamento no primeiro dia e durante o TIM. A CK teve aumento significativo depois do treinamento em cada semana, mas o aumento 24 horas depois de TE foi expressivamente maior do que depois do primeiro dia e do TIM. Conclusões: 0 aumento drástico da intensidade máxima do exercício de sprint repetido resulta em maior dano muscular relativo, mesmo em indivíduos treinados, o que limitará substancialmente seu desempenho. Outras sessões de treinamento, mesmo em intensidade e volume normais, com tempo insuficiente para recuperação muscular, podem prolongar a duração da fadiga. Nível de evidência ll; Estudos Diagnósticos - Investigação de exame diagnóstico.

Descritores: Creatina Quinase; Cortisol; Flexibilidade; Força Muscular; Treinamento Intervalado de Arranque; Fadiga Muscular.

\section{RESUMEN}

Introducción: No existe ningún estudio anterior que haya analizado las respuestas a las lesiones musculares provenientes de las alteraciones de la carga de entrenamiento en individuos entrenados exclusivamente con ejercicios repetitivos 
de carrera. Objetivos: La propuesta de este estudio fue examinar el efecto de las alteraciones de la carga de entrenamiento sobre el desempeño físico y las lesiones musculares inducidas por el ejercicio en atletas universitarios del sexo masculino que fueron entrenados usando un protocolo de sprint (entrenamiento de alta intensidad) de 30 metros repetido. Métodos: Doce participantes concluyeron el período de entrenamiento de seis semanas (tres sesiones/semana), que consistió en aumentar progresivamente el entrenamiento de intensidad en las primeras cinco semanas. En el primer día del período de entrenamiento, todos los sprints fueron realizados con 70\% a 80\% del esfuerzo máximo. En la primera sesión de la 5 a semana (entrenamiento de intensidad máxima, EIM), todos los sprints $(10 \times 30$ m) fueron realizados en la velocidad máxima. Las series (10 sprints en la velocidad máxima en cada serie) fueron repetidas hasta la extenuación (entrenamiento exhaustivo, EE) en la primera sesión de entrenamiento de la 6 a semana, seguidas de dos sesiones de entrenamiento normal. La fuerza isométrica, el desempeño en el sprint de 30 metros, la flexibilidad, la creatina quinasa sérica (CK) y el cortisol fueron medidos periódicamente durante el período de entrenamiento. Resultados: La fuerza isométrica, el desempeño en el sprint de 30 metros y la flexibilidad disminuyeron significativamente después del EE y no fueron recuperados durante el período de 9 días siguientes, que consistió en dos sesiones de entrenamiento y seis días de recuperación. El cortisol tuvo elevación significativa inmediatamente después del EE, pero no tuvo alteración después del entrenamiento en el primer día y durante el EIM. La CK tuvo aumento significativo después del entrenamiento en cada semana, pero el aumento 24 horas después de EE fue expresivamente mayor que después del primer día y del EIM. Conclusiones: El aumento drástico de la intensidad máxima del ejercicio de sprint repetido resulta en mayor daño muscular relativo, aún en individuos entrenados, lo que limitará sustancialmente su desempeño. Otras sesiones de entrenamiento, aún en intensidad y volumen normales, con tiempo insuficiente para recuperación muscular, pueden prolongar la duración de la fatiga. Nivel de evidencia ll; Estudios Diagnósticos - Investigación de examen diagnóstico.

Descriptores: Creatina Quinasa; Cortisol; Flexibilidad; Fuerza Muscular; Entrenamiento por Intervalos de Sprint; Fatiga Muscular.

\section{INTRODUCTION}

Multiple-sprint sports such as basketball, rugby and soccer require brief periods of high intensity and low intensity repeated running through either daily practice or matches. ' It has been documented that in sprinting, eccentric muscle contractions during the landing phase results in muscle damage..$^{2-4}$ It is widely accepted that the repeated microtraumas that occur throughout a season during both training and competition may have provided some degree of sensitization of the muscles. ${ }^{5}$ Efflux of the intramuscular enzyme creatine kinase (CK) into the blood ${ }^{6}$ and prolonged decrements in muscle function as evidenced by reductions in isometric strength, ${ }^{7,8,9}$ range of motion, ${ }^{9}$ and rapid dynamic muscle functions ${ }^{10-12}$ are discussed in the literature as some of the symptoms for muscle damage. If these symptoms persist, athletic performance is likely to be affected. The magnitude of muscle damage is determined by training load together with individual's recovery ability. ${ }^{13-15}$

The ability to perform repeated sprints with minimal recovery between sprint bouts is considered an important fitness component in multiple-sprint sports. ${ }^{1}$ It has been documented that a $30 \mathrm{~m}$ repeated sprinting protocol results in muscle damage., ${ }^{4,16}$ However, there is no previous study examining the muscle damage responses from training load changes in individuals trained by only repeated sprint exercise protocol, during the training period. The purpose of this study was to examine the effect of training load changes on physical performance and exercise-induced muscle damage in college athletes who were trained by repeated sprint training.

\section{METHODS}

\section{Participants}

Twelve healthy male subjects (mean \pm SD; age $24 \pm 3.5$ years, height $178.5 \pm 5.8 \mathrm{~cm}$, weight $72.8 \pm 8.6 \mathrm{~kg}$ ) volunteered to participate in the present study. All the subjects were university-level athletes from various team sport backgrounds competing (at least 4 years) and training at least three times a week. The study was explained to all participants in detail, and written informed consent forms were acquired. Measurements were performed following the approval of the Cukurova University Medical Faculty Ethics Committee and carried out in accordance with the Declaration of Helsinki (200711). During the study, the subjects were not allowed to perform any physical activity that would impact the results of the study.

\section{Training and testing procedures}

The subjects were trained 3-day a week for 6-week. All training sessions were performed on Mondays, Tuesdays, and Thursdays. During training, the subjects were asked to perform consecutive $30 \mathrm{~m}$ sprints. One set was composed of 10 repetitions and the subjects performed one set in the $1^{\text {st }}$ and $2^{\text {nd }}$ sessions of each week and two sets in the $3^{\text {rd }}$ session of each week. In the first 5-week, the subjects were adapted to the intensity (based on a percentage of the individual maximum effort) of the training which increased gradually in the first training session of the each week. (Table 1; Figure 2)

Maximal intensity training session (MIT): In the $1^{\text {st }}$ session of the $5^{\text {th }}$ week, all sprints were performed at the maximal speed.

Exhaustive training session (ET): In the $1^{\text {st }}$ training session of the $6^{\text {th }}$ week, the subjects were asked to perform a maximum number of sets to the point of exhaustion. The exercise was terminated when the subject reached volitional fatigue. All sprint sets were performed at the maximal speed. ET was followed by regular training sessions as in the adaptive training period. Subjects were asked to train their weekly routine in the $2^{\text {nd }}$ and $3^{\text {rd }}$ sessions of the $6^{\text {th }}$ week. At the end of final training session, 6 days of recovery were given without any training.

Subjects'30m sprint performance was measured before and 24-hour after training in the first session of each week throughout the training period. Isometric strength and flexibility were measured before, immediately after, and 24-hour after the first day of the training program, MIT and ET. In addition, all performance measurements (after a standardized 15-minute warm-up) were made 72 -hour after ET and the $2^{\text {nd }}, 4^{\text {th }}$ and $6^{\text {th }}$ days of recovery. Blood samples were taken before, immediately after and 24-hour after the first day, MIT and ET, and 72-hour after ET. (Figure 1) To minimize the time effect, all training and measurements were performed at the same time of day for each subject. 
Table 1. Weekly program for the 6 weeks of repeated sprint training.

\begin{tabular}{|c|c|c|c|}
\hline & Session & $\begin{array}{c}\text { Volume } \\
\text { sets } \times \text { repetitions }\end{array}$ & $\begin{array}{c}\text { Intensity } \\
\% \text { maximum effort }\end{array}$ \\
\hline \multirow{3}{*}{ Week 1} & $1^{\text {st }}$ & $1 \times 10$ & $70-80 \%$ \\
\hline & $2^{\text {nd }}$ & $1 \times 10$ & $70-80 \%$ \\
\hline & $3^{\text {rd }}$ & $2 \times 10$ & $70-80 \%$ \\
\hline \multirow{3}{*}{ Week 2} & $1^{\text {st }}$ & $1 \times 10$ & $\begin{array}{c}2 \text { sprints at } 100 \% \\
8 \text { sprints at } 70-80 \%\end{array}$ \\
\hline & $2^{\text {nd }}$ & $1 \times 10$ & $70-80 \%$ \\
\hline & $3^{\text {rd }}$ & $2 \times 10$ & $80-90 \%$ \\
\hline \multirow{3}{*}{ Week 3} & $1^{\text {st }}$ & $1 \times 10$ & $\begin{array}{c}4 \text { sprints at } 100 \% \\
6 \text { sprints at } 70-80 \%\end{array}$ \\
\hline & $2^{\text {nd }}$ & $1 \times 10$ & $70-80 \%$ \\
\hline & $3^{\text {rd }}$ & $2 \times 10$ & $80-90 \%$ \\
\hline \multirow{3}{*}{ Week 4} & $1^{\text {st }}$ & $1 \times 10$ & $\begin{array}{l}5 \text { sprints at } 100 \% \\
5 \text { sprints at } 90 \%\end{array}$ \\
\hline & $2^{\text {nd }}$ & $1 \times 10$ & $80-90 \%$ \\
\hline & $3^{\text {rd }}$ & $2 \times 10$ & $80-90 \%$ \\
\hline \multirow{3}{*}{ Week 5} & $1^{\text {st }}(\mathrm{MIT})$ & $1 \times 10$ & $100 \%$ \\
\hline & $2^{\text {nd }}$ & $1 \times 10$ & $80-90 \%$ \\
\hline & $3^{\text {rd }}$ & $2 \times 10$ & $80 \%$ \\
\hline \multirow{3}{*}{ Week 6} & $1^{\text {st }}(E T)$ & All out & $100 \%$ \\
\hline & $2^{\text {nd }}$ & $1 \times 10$ & $80-90 \%$ \\
\hline & $3^{\text {rd }}$ & $2 \times 10$ & $80 \%$ \\
\hline
\end{tabular}

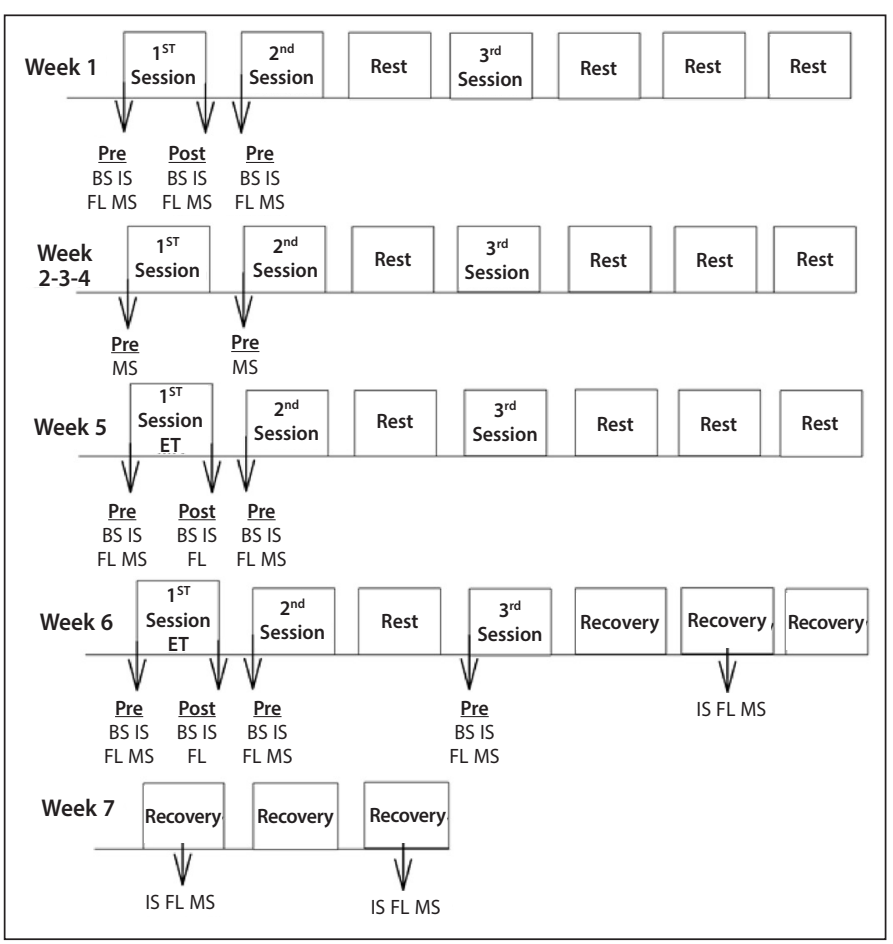

Figure 1. Study design. BS= Blood sampling, IS= Isometric strength, FL= Flexibility, $\mathrm{MS}=$ Maximal sprint.

\section{Training protocol}

All training sessions were performed on a $60 \mathrm{~m}$ indoor track at $\mathrm{Cu}$ kurova University Sports Physiology Laboratory. Before the training sessions, the subjects completed a standardized 15 min warm-up period, involving light jogging, a series of dynamic sprint drills, stretching, and several acceleration runs. Subjects were tested prior to the $1^{\text {st }}$ and $2^{\text {nd }}$ training sessions of each week and the final training session, therefore completing their regular warm-up prior to testing. The training consisted of $30 \mathrm{~m}$ repeated sprints interspersed with 30-second of active jogging recovery. Each set was interspersed with 5 min of passive recovery. During the active recovery period between sprints, the subjects decelerated within the $10 \mathrm{~m}$ distance after passing the finish line and jogged back to the starting line. Sprint times were measured with infrared light sensors connected to a timing device (New test Oy, Oulu, Finland). The recovery time was controlled by hand-held stopwatch.

\section{Maximal isometric strength}

Maximal isometric knee extension strength from the dominant leg was measured with an isokinetic dynamometer (Cybex, Norm 6000). The dynamometer was set up according to manufacturer's instructions; the joint angle was set at $60^{\circ}$ of extension and gravity compensation was employed to allow for inter subject variations in moment acting upon limb weight. All participants completed two tests with 5 -second duration and were separated with 60-second recovery period. Standardized verbal instructions and encouragements were provided throughout the protocol. The best peak isometric strength value was used in the data analysis.

\section{Sit and reach test (SRT)}

A standard sit-and-reach box was used to measure the subjects' flexibility. ${ }^{17}$ SRT is typically used to evaluate flexibility of the low back and hamstring muscles. Subjects were seated on the floor with their bare feet touching the box. The subjects then slowly reached forward towards their toes while keeping their legs straight and their hands together pushing the sliding ruler that was centered on the top of the box to obtain the SRT scores. The test was performed three times and the best score was recorded.

\section{$30 \mathrm{~m}$ sprint test}

The subjects stood $30 \mathrm{~cm}$ behind the start line to avoid premature triggering of the timing system and completed three maximal sprints which were separated by 60 -second of recovery. The fastest $30 \mathrm{~m}$ sprint time was recorded for data analysis.

\section{Blood analysis}

Blood samples $(10 \mathrm{ml})$ were collected from the antecubital vein for serum CK and cortisol measurements. Whole blood was allowed to clot at room temperature. Subsequently, blood was centrifuged at $3500 \mathrm{rpm}$ for 5-minute and was separated into serum. Serum CK and cortisol levels were determined immediately. CK was measured with colorimetric assay procedure and cortisol was measured with electrochemiluminescence immunoassay (Elecsys Modular Analytics E170; Roche Diagnostics, Mannheim, Germany). All blood sampling processes were performed at the same time of the day.

\section{Statistical analyses}

Changes in isometric strength, flexibility, 30m sprint time and cortisol over time were analyzed using a repeated measures analysis of variance (ANOVA). Bonferroni correction was used as a post hoc test when main effects were found to be significant. CK data were not normally distributed, determined by the Kolmogrov-Smirnov and Shapiro-Wilk normality tests. Therefore, Friedman's nonparametric test was used to determine whether significant changes occurred with time for the CK data, and changes were located with Wilcoxon's matched-pair signed-rank test. Other parameters in the study were normally distributed. Statistical significance was accepted at $p<0.05$. The values were reported as mean \pm standard deviation (S.D.). The SPSS version 16 was used for all analyses (16, SPSS Inc. Chicago, IL).

\section{RESULTS}

In the ET, one subjects performed 17 sprints, four subjects performed 20 sprints, one subjects performed 24 sprints, one subjects performed 26 sprints, one subjects performed 30 sprints, one subjects performed 
35 sprints, one subjects performed 40 sprints, one subjects performed 46 sprints and one subjects performed 50 sprints. There was no significant difference in mean sprint time (10 repetitions) between MIT ( $4.28 \pm 0.1 \mathrm{sec})$ and the first set of ET $(4.27 \pm 0.1 \mathrm{sec})(p>0.05$. (Figure 2)

$30 \mathrm{~m}$ sprint times measured before the first training session of each week were $4.28 \pm 0.2,4.21 \pm 0.1,4.17 \pm 0.1,4.09 \pm 0.1,4.11 \pm 0.1$ and $4.07 \pm 0.1 \mathrm{sec}$, respectively for the $1^{\text {st }}, 2^{\text {nd }}, 3^{\text {rd }}, 4^{\text {th }}, 5^{\text {th }}$ and $6^{\text {th }}$ weeks. $30 \mathrm{~m}$ sprint performance was improved significantly at the $3^{\text {rd }}, 4^{\text {th }}, 5^{\text {th }}$ and $6^{\text {th }}$ weeks compared to initial $(p<0.01)$. (Figure 3 )

$30 \mathrm{~m}$ sprint times measured 24-hour after training in the $1^{\text {st }}(4.28 \pm$ $0.2 \mathrm{sec}), 2^{\text {nd }}(4.27 \pm 0.2 \mathrm{sec}), 3^{\text {rd }}(4.2 \pm 0.2 \mathrm{sec}), 4^{\text {th }}(4.11 \pm 0.1 \mathrm{sec})$ and $5^{\text {th }}$ $(4.11 \pm 0.2 \mathrm{sec})$ weeks, was not significantly different from the pre-training value ( $p>0.05$ ). However, a significant reduction in the sprint performance was observed at $24(4.18 \pm 0.2 \mathrm{sec}, \mathrm{P}<0.05)$ and 72 -hour (4.24 $\pm 0.2 \mathrm{sec}, \mathrm{P}<0.001)$ after ET. Sprint performance during 6-day recovery period was still significantly lower than the pre-ET value $\left(4.29 \pm 0.3,4.2 \pm 0.2\right.$ and $4.17 \pm 0.1 \mathrm{sec}$ for the $2^{\text {th }}, 4^{\text {th }}$ and $6^{\text {th }}$ days of recovery, respectively, $\mathrm{P}<0.05$, Figura 3 ).

The pre-training isometric strength at the ET was significantly higher than the first day and MIT ( $p<0.05$ ). (Table 2 ) Immediately after and 24-hour after MIT, the isometric strength was unchanged compared to the pre-training value $(p>0.05)$. A significant immediate decrease in the isometric strength was found at the first day $(P<0.05)$ and $E T(P<0.01)$.

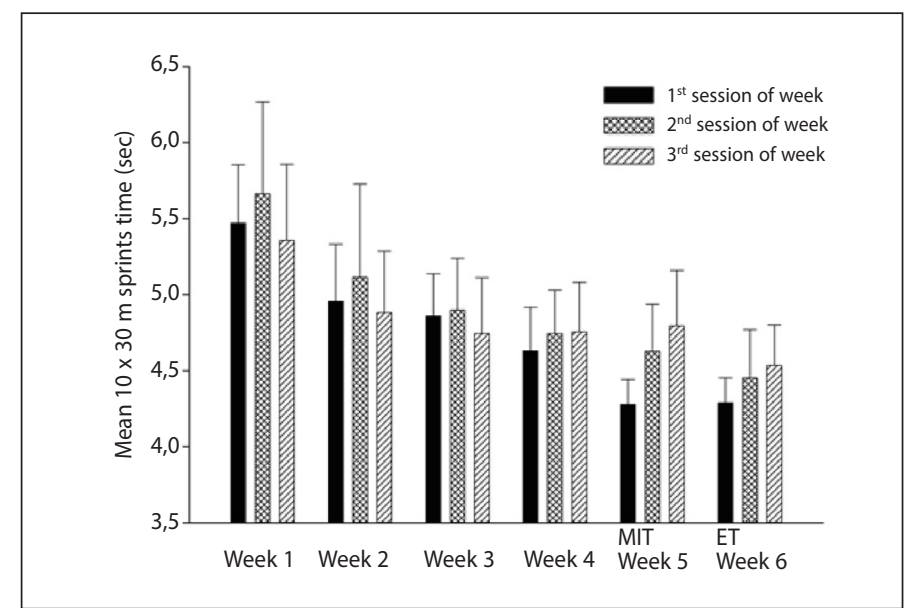

Figure 2. Weekly training intensity (mean $10 \times 30 \mathrm{~m}$ sprint time \pm SD) for the three training sessions of each week (Average running speed was not different for the MIT and ET - note; mean value of the first set of data is given in the figure for the ET and the 3rd session of each week).

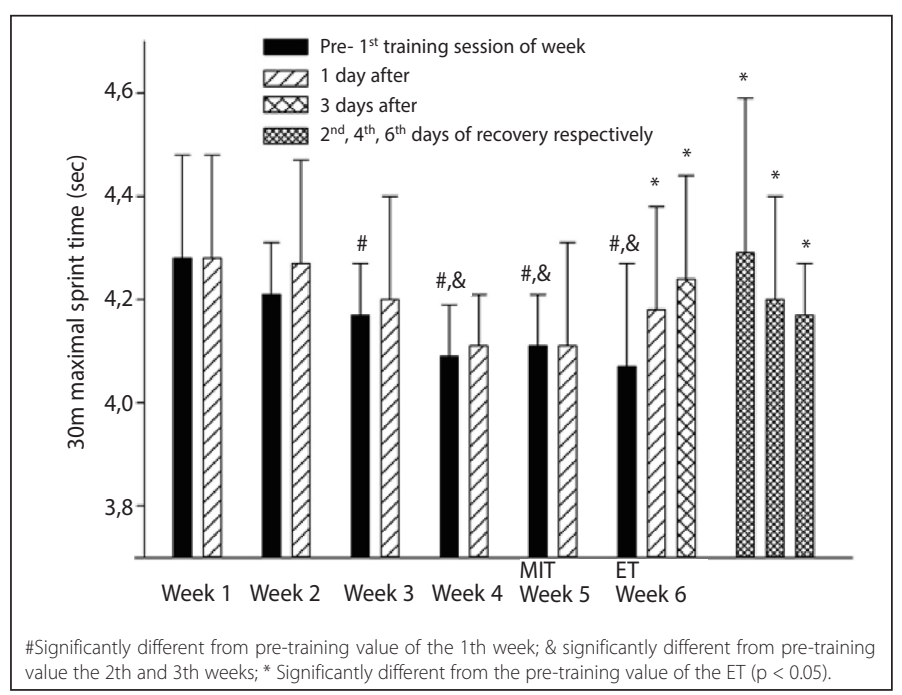

Figure 3. Changes in $30 \mathrm{~m}$ sprint performance before and after the first training session of each week (mean $\pm \mathrm{SD}$ ). 24-hour after the first day, isometric strength returned to the pre-training value $(p>0.05)$. Significant decrement in the isometric strength was observed at 24 and 72 -hour after $E T(P<0.05)$. The subjects had not been able to recover completely during the 6-day recovery period and all the values were significantly lower than the pre-ET value $(P<0.05)$.

Pre-training flexibility was not significantly different among the first day, MIT and ET (p>0.05). (Table 2) The subjects' flexibility in both the first day and MIT did not change immediately after training, but decreased significantly 24-hour after training compared to pre-training value $(P<0.05)$. A significant decrement in the flexibility was observed immediately after, 24-hour, and 72-hour after ET $(P<0.05)$. The subjects' flexibility remained significantly lower during the recovery period when compared to the pre-ET value $(P<0.05)$.

Pre-training serum CKand cortisol levels were not significantly different among the first day, MIT and ET ( $p>0.05$ ). (Table 3) CKincreased significantly immediately after training $(P<0.01)$ and 24-hour after training $(P<0.01)$ when compared to pre-training values. 24-hour after the ET, the increase was significantly higher when compared to the first day and MIT $(P<0.01)$. CK was still significantly higher 72-hour after training compared to the pre-training values of the $E T(P<0.01)$. Cortisol only elevated significantly immediately after the ET $(p<0.001)$ when compared to pre-training values.

Table 2. Changes in the isometric strength and flexibility of subjects during the study period.

\begin{tabular}{c|c|c|c}
\hline \multicolumn{2}{c|}{ Measure } & Isometric Strength (N) & Flexibility (cm) \\
\hline \multirow{4}{*}{$\begin{array}{c}\text { First day } \\
\text { Week 1 }\end{array}$} & Pre-training & $250 \pm 35.2^{\#}$ & $28.3 \pm 4.4$ \\
\cline { 2 - 4 } & Post-training & $231 \pm 27.5^{*}$ & $28.4 \pm 4.7$ \\
\cline { 2 - 4 } & $24 \mathrm{hr}$ after & $234.3 \pm 36.1$ & $26.5 \pm 5^{*}$ \\
\hline \multirow{4}{*}{$\begin{array}{c}\text { MIT } \\
\text { Week 5 }\end{array}$} & Pre-training & $267.8 \pm 45.1^{\#}$ & $28.2 \pm 4.6$ \\
\cline { 2 - 4 } & Post-training & $258.8 \pm 39.3$ & $27.7 \pm 4.2$ \\
\cline { 2 - 4 } & 24 hr after & $275.6 \pm 39.3$ & $26.4 \pm 4.7^{*}$ \\
\hline \multirow{4}{*}{$\begin{array}{c}\text { ET } \\
\text { Week 6 }\end{array}$} & Pre-training & $284.4 \pm 52.5$ & $28.1 \pm 4.2$ \\
\cline { 2 - 4 } & Post-training & $243.9 \pm 32.4^{*}$ & $26.3 \pm 4.1^{*}$ \\
\cline { 2 - 4 } & 24 hr after & $259.7 \pm 40.4^{*}$ & $25.3 \pm 5.5^{*}$ \\
\cline { 2 - 4 } & 72 hr after & $267.1 \pm 45.6^{*}$ & $25.5 \pm 5.5^{*}$ \\
\hline \multirow{4}{*}{ Recovery } & $2^{\text {th }}$ day & $260.7 \pm 42.1^{\#}$ & $24.8 \pm 5^{\#}$ \\
\cline { 2 - 4 } & $4^{\text {th }}$ day & $266.2 \pm 47.3^{\#}$ & $25.8 \pm 5.1^{\#}$ \\
\cline { 2 - 4 } & $6^{\text {th }}$ day & $262.2 \pm 49.9^{\#}$ & $26.5 \pm 4.9^{\#}$ \\
\hline
\end{tabular}

Values are means $\pm S D ;{ }^{*}$ Significantly different from pre-training values of the each week $(P<0.05)$. \& Significantly different from pre-training values of the first week $(P<0.05)$. \# Significantly different from pre-training values of the $6^{\text {th }}$ week $(P<0.05)$.

Table 3. Changes in the serum creatine kinase and cortisol levels following the first day, MIT and ET.

\begin{tabular}{c|c|c|c|c}
\hline \multicolumn{2}{c|}{} & $\begin{array}{c}\text { First day } \\
\text { Week 1 }\end{array}$ & $\begin{array}{c}\text { MIT } \\
\text { Week 5 }\end{array}$ & $\begin{array}{c}\text { ET } \\
\text { Week 6 }\end{array}$ \\
\hline \multirow{4}{*}{$\begin{array}{c}\text { Creatine } \\
\text { Kinase }(U / L)\end{array}$} & Pre-training & $196 \pm 103.3$ & $176.2 \pm 70.3$ & $153.7 \pm 29.5$ \\
\cline { 2 - 5 } & Post-training & $248.8 \pm 121.6^{*}$ & $223.8 \pm 86.1^{*}$ & $223.6 \pm 47^{*}$ \\
\cline { 2 - 5 } & $24 \mathrm{hr}$ after & $406 \pm 304.1^{*}, 8$ & $377.7 \pm 245.9^{*}, 8$ & $647.7 \pm 366^{*}$ \\
\cline { 2 - 5 } & $72 \mathrm{hr}$ after & & & $380.7 \pm 247^{*}$ \\
\hline \multirow{4}{*}{$\begin{array}{c}\text { Cortisol } \\
(\mu \mathrm{g} / \mathrm{dl})\end{array}$} & Pre-training & $13.5 \pm 3.3$ & $13.2 \pm 4$ & $13.5 \pm 4.2$ \\
\cline { 2 - 5 } & Post-training & $14 \pm 6$ & $15.2 \pm 4.6$ & $25.9 \pm 3.9^{*}$ \\
\cline { 2 - 5 } & $24 \mathrm{hr}$ after & $13.5 \pm 5.6$ & $12.9 \pm 3$ & $12.5 \pm 2.7$ \\
\cline { 2 - 5 } & $72 \mathrm{hr}$ after & & & $15.1 \pm 3.9$ \\
\hline
\end{tabular}

Values are means $\pm S D ;{ }^{*}$ Significantly different from pre-training value of each training session $(P<0.05)$; \& significantly different from 24 hours after ET $(p<0.05)$. 


\section{DISCUSSION}

The main finding of this study is that during the training period, a single session of exhaustive exercise may cause long-term performance reduction even in regularly trained individuals. These data suggest that regular performance evaluation together with CK and cortisol may be useful for monitoring training stress and tolerance to training.

In this study, the training program was based on the progressive overloading principle ${ }^{18,19}$ and training intensity was increased progressively through the 5-week period. Sprint performance improvement may be accepted as evidence of our training program's efficiency. Through the 5-week period, subjects had been able to recover within 24 hours following the first training session of each week. On the other hand, exercise to the point of exhaustion as performed in the $6^{\text {th }}$ week of the study was improper stress for the subjects and caused a significant decrement in 30m sprint performance, muscle strength and flexibility. Moreover, subjects had not been able to recover in the following 9-day period which consisted of two training sessions and 6-day of recovery. As noted earlier, 15,19,20 following strenuous training, a performance reduction may be attributed to muscle damage. Long term decrement in athletic performance together with an increase in CK have been reported during and/or after the intensified training period. ${ }^{19,20,21}$ Only a one-day exhaustive training session as performed in our study resulted in a long term reduction of performance. The time needed to recover performance after ET was greater than the previous weeks' training sessions. Despite low intensity and volume training performed in the following two training sessions, the imbalance between training and recovery may have prolonged the duration of fatigue. Such performance reduction can also be seen following an "all out" competition.

It has been documented that repeated sprinting with rapid deceleration may have the potential to induce muscle damage. ${ }^{4,16}$ The increases in CK following repeated sprint exercise provide evidence of skeletal muscle fiber damage. ${ }^{4,16}$ Isometric strength is thought to be the most accurate and reliable indirect marker of muscle damage ${ }^{8}$ and is known to remain depressed for several days after exercise. ${ }^{7,9} \mid$ sometric strength of the knee extensors has been shown to decrease 24 and 48-hour after repeated sprint exercise. ${ }^{4}$ It has also been shown that sprinting performance ${ }^{10,22}$ and flexibility 23,24 reduction is associated with muscle damage. In this study, sprint performance, isometric strength, and flexibility were reduced following the ET. All of these findings together with the increased post-training CK may indicate the presence of muscle tissue damage caused by repeated sprinting.

It is known that increasing the number of eccentric contractions produces greater muscle damage. ${ }^{13,14}$ The time needed for muscle recovery depends on the severity of the muscle damage. ${ }^{13,14}$ In this study, although training increased serum CK following both the first day and MIT, it did not negatively affect performance during successive days. A higher increase in CK was observed when the sets were repeated until exhaustion in the ET. In addition, ET had a long term negative effect on muscle performance. The training volume was possibly greater than subjects were accustomed to, thereby causing greater severity muscle damage by ET despite relatively well-trained subjects.

An exercise is particular form of metabolic and physical stress which is shown to be a potent activator of the hypothalamo-pituitary-adrenal axis (HPA), increasing cortisol levels. ${ }^{25,26}$ Training intensity and duration are one of the determinants of the HPA response to exercise. ${ }^{26,27}$ The exercise-induced increase in the blood cortisol is essential for normal metabolic response and adaptation to exercise. ${ }^{28}$ On the other hand, it has been considered that resting cortisol generally reflect a long-term training stress. ${ }^{28,29}$ Significantly elevated cortisol levels following the ET indicate that this type of physical activity was enough to cause a stressful situation for the body. Insignificant post-training cortisol changes in the first day of the training program may be explained by the low intensity of the training. Whereas in MIT, due to the possible adrenal adaptation of the subjects, ${ }^{30}$ cortisol may not have changed significantly even when exercise intensity was increased compared to the beginning.

\section{CONCLUSION}

Relatively greater muscle damage and hence more severe symptoms can be observed even in regularly trained individuals when the volume of maximal intensity repeated sprint exercise is increased dramatically during the training period. If adequate recovery is not allowed during subsequent training sessions even at normal intensity and volume, it may prolong the duration of fatigue.

All authors declare no potential conflict of interest related to this article

AUTHORS' CONTRIBUTIONS: Each author made significant individual contributions to this manuscript. SKE (0000-0002-3680-3580)* and ZA (0000-0003-1850-7048)*: were responsible for data collection, data analysis and interpretation, and the writing of the draft; ÇÖ (0000-0003-3360-8541)*: assisted in data analysis and interpretation; KÖ (0000-0002-68406299)* and SK (0000-0002-0797-046X)*: designed the study and supervised the data collection, analysis, and the writing of the manuscript. All authors read and approved the final manuscript. *ORCID (Open Researcher and Contributor ID).

\section{REFERENCES}

1. Spencer M, Bishop D, Dawson DB, Goodman C. Physiological and metabolic responses of repeated sprint activities: specific to field based team sports. Sports Med. 2005;35(12):1025-44.

2. Thompson D, Nicholas CW, Williams C. Muscular soreness following prolonged intermittent high-intensity shuttle running. J Sports Sciences. 1999;17(5):387-95.

3. Fridén J, Seger J, Ekblom B. Sublethal muscle fibre injuries after high-tension anaerobic exercise. Eur J Appl Physiol. 1988:57(3):360-8

4. Howatson G, Milak A. Exercise-induced muscle damage following a bout of sport specific repeated sprints. J Strength Cond Res. 2009;23(8):2419-24

5. Hoffman JR, Kang J, Ratamess NA, Faigenbaum AD. Biochemical and hormonal responses during an intercollegiate football season. Med Sci Sports Exerc. 2005;37(7):1237-41.

6. Brancaccio P, Maffulli N, Limongelli FM. Creatine kinase monitoring in sport medicine. Br Med Bull. 2007;81-82:209-30.

7. Clarkson PM, Nosaka K, Braun B. Muscle function after exercise-induced muscle damage and rapid adaptation. Med Sci Sports Exerc. 1992;24(5):512-20.

8. Warren GL, Lowe DA, Armstrong RB. Measurement tools used in the study of eccentric contraction induced injury. Sports Med. 1999;27(1):43-59.
9. Cleak MJ, Eston RG. Muscle soreness, swelling, stiffness and strength loss after intense eccentric exercise. Br J Sports Med. 1992;26(4):267-72.

10. Twist $C$, Eston RG. The effects of exercise-induced muscle damage on maximal intensity intermittent exercise performance. Eur J Appl Physiol. 2005;94(5-6):652-8.

11. Byrne C, Twist C, Eston RG. Neuromuscular function following exercise-induced muscle damage: theoretical and applied implications. Sports Med. 2004;34(1):49-69.

12. Byrne C, Eston RG. The effect of exercise induced muscle damage on isometric and dynamic knee extensor strength and vertical jump performance. J Sport Sci. 2002;20(5):417-25.

13. Nosaka K, Newton M. Difference in the magnitude of muscle damage between maximal and submaximal eccentric loading. J Strength Cond Res. 2002;16(2):202-8.

14. Clarkson PM, Tremblay I. Exercise-induced muscle damage, repair and adaptation in humans. J Appl Physiol. 1988;65(1):1-6

15. Simith LL. Cytokine hypothesis of overtraining: A physiological adaptation to excessive stress? Med Sci Sports Exerc. 2000;32(2):317-31.

16. Keane KM, Salicki R, Goodall S, Thomas K, Howatson G. Muscle damage response in female collegiate athletes after repeated sprint activity. J Strength Cond Res. 2015;29(10):2802-7. 
17. Hopkins DR, Hoeger WWK. A comparison of the sit-and-reach test and the modified sit-and-reach test in the measurement of flexibility for males. J Appl Sport Sci Res. 1992;6(1):7-11.

18. Fry AC, Kraemer WJ. Resistance exercise overtraining and overreaching. Neuroendocrine responses. Sports Med. 1997;23(2):106-29.

19. Coutts AJ, Reaburn P, Piva TJ. Murphy A. Changes in selected biochemical, muscular strength, power and endurance measures during deliberate overreaching and tapering in rugby league players. Int $J$ Sports Med. 2007;28(2):116-24.

20. Coutts AJ, Reaburn P, Rowsell GJ. Monitoring for overreaching in rugby league players. Eur J Appl Physiol. 2007;99(3):313-24.

21. Halson SL, Lancaster G, Jeukendrup AE, Gleeson M. Immunological responses to overreaching in cyclists. Med Sci Sports Exerc. 2003;35(5):854-61.

22. Highton J, Twist C, Eston RG. The effects of exercise-induced muscle damage on agility and sprint running performance. J Exerc Sci Fit. 2009;7(1):24-30.

23. Worrell TW, Perrin DH, Cansneder B, Cieck I. Comparison of isokinetic strength and flexibility measures between hamstring injured and noninjured athletes. J Orthop Sports Phys Ther. 1991;13(3):118-25.
24. Askling C, SaartokT, Thorstensson A. Type of acute hamstring strain affects flexibility, strength, and time to return to pre-injury level. Br J Sports Med. 2006;40(1):40-1.

25. Buono MJ, Yeager JE, Hodgon JA. Plasma adrenocorticotropin and cortisol responses to brief high-intensity exercise in humans. J Appl Physiol. 1986;61(4):1337-9.

26. Luger A, Deuster PA, Kyle SB, Gallucci WT, Montgomery LC, Gold PW, et al. Acute hypothalamic-pituitary adrenal responses to the stress of treadmill exercise. Physiologic adaptations to physical training. N Eng J Med. 1987;316(21):1309-15.

27. Kuoppasalmi K, Naveri H, Harkonen M, Adlercreutz H. Plasma cortisol, androstenedione, testosterone and luteinizing hormone in running exercise of different intensities. Scand J Clin Lab Invest. 1980;40(5):403-9.

28. Kraemer WJ, Ratamess NA. Hormonal Responses and Adaptations to Resistance Exercise and Training Sports Med. 2005;35(4):339-61.

29. Purge $P$, Jürimäe T, Jürimäe J. Hormonal and psychological adaptation in elite male rowers during prolonged training. J Sports Sciences. 2006;24(10):1075-82.

30. Silva TS, Longui CA, Faria CDC, Rocha MN, Melo MR, Faria TG, et al. Impact of prolonged physical training on the pituitary glucocorticoid sensitivity determined by very low dose intravenous dexamethasone suppression test. Horm Metab Res. 2008:40:718-21. 